資 料

\title{
昭和肥料川崎工場設立の事情並に經過
}

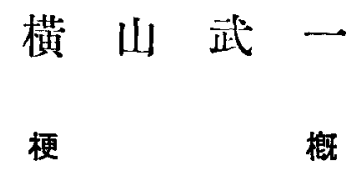

日本式アムモニア合成法を實施した本邦硫安界に, 否本邦化學工業界に葛丈の氣索些くですらら事 を自負する昭和肥料川㥓工場に就いては既て余が工業化學第 11 回常會の席上講演し，之は同會誌 35 (昭 7) 842 に記載せらる」所であるが玆に恃更に重椱する所もあるが電氣化學工䉾的立場から今 一度梆へる事とする。

\section{I. 研究所時代}

大正 7 年寺內内閣賞時臨時窒素肥料研究所官制が發布 され現東京工業試驗所長小寺房治郎博士（賞時工業試驗 所第五部長) が其の所長に任命されて。此空素研究所は 全く當時世間で大問題となつて居た䇪素工業確立に資す る䉆めであって，窒素問題と然料問題は富しく論議され て居た時代である。之は全く當時䤃なりし世界大戰の影 響に体るもので，肥料としてょりも軍需品としてアムモ こアは箽要視せられ，臨時窒䒺研究所賞面め閣題は如何 にしてアムモニアを合成し，又如何に之を酸化して确酸 を得ぺをかてあつた。燃料問題は資源に乏しを雹め未だ

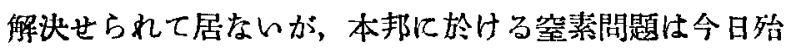
ぞ解决されて居る。本邦に於ける硫安は既に自給自足上 りー步進んで近く輸出に轉淌すべき運命に置かれて居

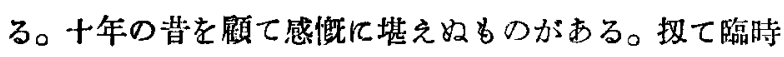
窒素研究所の出來を當時余は工業試驗所第五部に奉䕙し 小寺部長の下に Schönherr 式空策硝酸製造試驗に從事 して居をが装 8 年 5 月此の試驗終了之共江窒素研究所

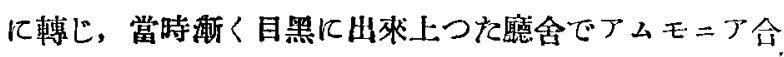
成に關する試驗研究を行ふ事になつたのである。現昭和 肥料技们中村健次郎氏及臺北帝大助敉授德闽松雄上等は 余の共同研究者であつた。而して柴田勝太郎氏及後には 菲司信守氏等は主として能媒の研究を行い余等は全く之
を工業化すると就て總括的稍大規模の試㯺を据辤し所謂 高慜工落といふ當時最初の仕事溥遇したのである。現

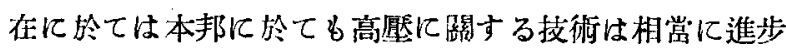
し 1,000 atm 位の㕌力で順調なる作業をして居る工場 もあるが，余等の實驗開始の㥧恃 $200 \mathrm{~atm}$ 义は $300 \mathrm{~atm}$

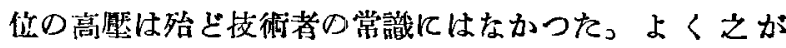
$200 \mathrm{lb} / \mathrm{in}^{2}$ 义は $300 \mathrm{lb} / \mathrm{in}^{2}$ の間違ぜやないかなど反間さ れを事もあつた。余の先輩てして久しく空氣液化つ試驗

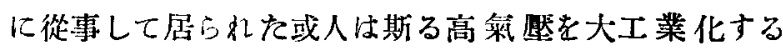

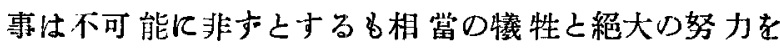
要する旨忠告して哭れたのである。化學實驗に於ては其

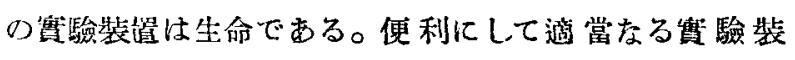
置があれば其の實驗は既に牛以上完成したといつている

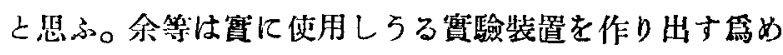
と努力の牛分を傾注したといつてい」。先づ最初の赛驗 裝置が出來てからは上く躅媒の研究と平行して裝置の改 良と工業化關するデータを作り得をのである。一體臨 時空素研究所は最初單にアムモニア合成とアムモニア酸

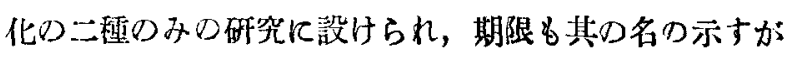
如く極めて短い臨時的のものであつてさらである。從つ てアムモニア合成といつても原料たる水素や窂素の製造

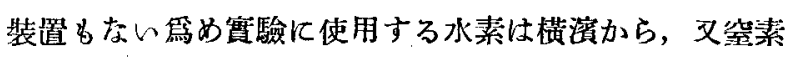
は九州からボムべ詰めたのを持つて來るといふ狀態で 
到底稍々大規模の貫驗の如きは思ひもよらなかつた。然 るに小折長の御骨折で原料の製造の研究も行はる小事 となり.大正 11 年頃には等素裝浩機も完成し, 13 年頃に は電解水素や Bamag 式蒸汽の緎分解法に依る水素製造

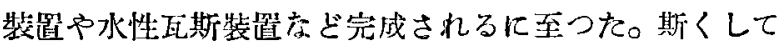
余等の惯驗も大正 11 年頃までは全く初期の小規模なる もので鲎時使用せるブムモニア合成管江現在川渏「場に て使用する合成菜の連絈管よりも細いものであつた。然

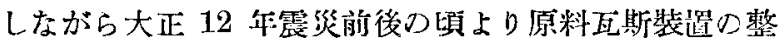

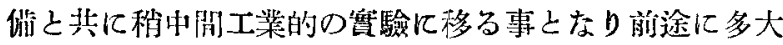
の寒光を眺めつ১此仕事に從事したっ此の間大正 9 年よ り 10 年に亘り約ーケ年余は官命索帶びて㰧米各國の咥

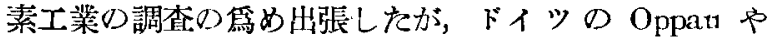
Leuna 工場の壯觀に感激し，叉當時日本に移植されん としつょあつたフランス Montereau K於ける Claude 式試驗工場を見學し多大の敎訓を得たのであつた。余の 歐米出張中此のフランスの Claude 法やイタリーの Casale 法を本邦に移植する話ば愛に進んで終に前者は クロード式空装工業會形彥島工湯として生れ，後者は日 本窒素肥料會社の延岡工場として生る」に至り，我々と しては自分の實驗作菜に拍車をかけたが合疼其の經過に

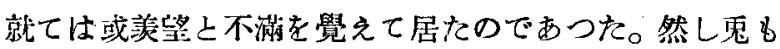
角爾束多少の迁餘曲折はあつたが小寺所長，北脇部長

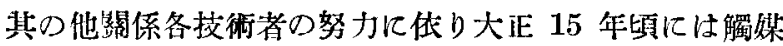

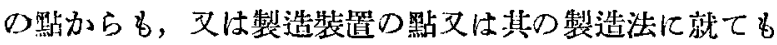
之をエ業化するに相䈏の確信が出來たりである。我々 はUhde 式の沈澱䚡媒の取扱に就ても Claude や Fauser 式等つ熔融觸梦の取扱に就ても一通りつ經驗を 得た。

昭和三年四月臨時空素研究所任東宗工澲試驗所第六部

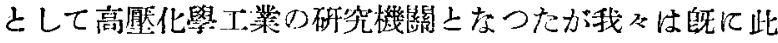
時までに所謂工業試驗所式アムモニア合成法の工業的設 計の基礎を造り得たのである。

\section{2. 昭和肥料川崎工場設立}

余が現在奉職する昭和肥料株式會社は昭和 3 年 10 月 の創立でする。從來專ら本邦に玷ける水力電氣の開登に
努力世る東信電氣株式會斻の堂事者は夙に過剩電打の沙 化とんふ，逆化電力需要者としての事業を目論見，東京 電燈株式會社と共同出資で昭和肥料株式會社を設立し, 其の第一期計畫として新潟縣東蔳原郡㪈瀨村に約 50,000 $\mathrm{kW}$ を消化する不灰空素工場を設方したのであるか，次 で第二期計畫として合成硫安工場の計唒を樹てた。而し

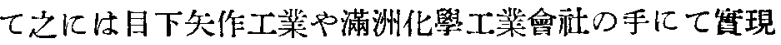
老㒻んとする Mont Cenis 法（メはUhde 法）の特許 が啗時䝴物に出て居たので先づ之を調整する事となり， 湍鐵，大同，昭和三社共同にて其の特許䝴牧料金中の若 干を支拂ひ現昭和肥料常務高橋保氏一行ひ渡㰧實地踏䍒 といふ段取よなつた。紧時余は未だ東京工業試驗所奉瞕 中だつたが依托の命を受けて此の一行に加はる事となり 昭和 3 年 10 月東京を出發した。而して我ょ一行は着猲早 た Mont Cenis 工場に赴いて實地視察をなしたのであ る。特に余及び現霂洲化學常務深水壽氏は 11 月上り 12 月に亘り約 40 日閣 Westfalen 地方 Herne 市郊外にあ る Mont Cenis 及び Hibernia の兩工場に日參して調 查した。其の調查の結果を玆に今公表する事を憚るが要

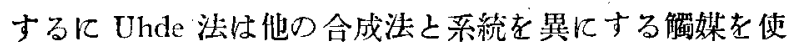
用する關係上非常に椱雜㷊作業系統有し其の作業法》 は觸媒の取扱等に著しく厄介があつた，然しよく考虑さ れ立派な設計ですつて，經濟的に他の方法より優秀なり とは斷定さ礼ないにしても，冭分價值もるものである事 が分つた。特に最近では此複雜性が漸吹除かれて單純化 されて來たといふ事である。所が之を本邦に移植するに 虽り特許つ買收は别として，機械設備の購入に就て妙な 行惩りが出來たのである。郎ち此の場合機栈類は保登保 項の存在する䉆め一切 Uhde 側の手を經て購入すべし と言し，而当其の值段たるや我々が充分調查せるものに

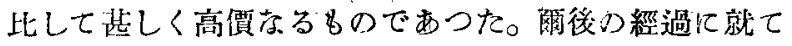
は雀略するが結局此の特許は買收せられ現に滿洲化學や 矢作工菜杜之に準據して合成法を營むかけであるが，昭 和側としては寧ろ Uhde 側の世話にならずにやり度いと いふ氣分になつて來た。其の時丁度 Fauser 式合成法に 關する特許買收に就て伂介する人が出て, 我店は、Fauser 
氏の案內でイタリーやベルギーの闹式工場數ろ所在视察 する機會を得た。而して此の閒約 2 週間赤は义 Fat1ser 氏よりも色及敎へられる所が多かつた。乙して絬局我に

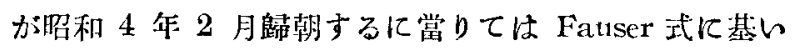
て工場を建てるといふ㭉を抱いて引揚げたのであるが，

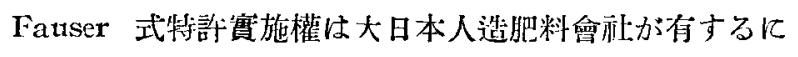
至り炤和が之を惯施するに就ても一寸困難なる事情に置 かれて昭和の鲎事者も去就に逃つた形で西つた。食は溜 歌中膺々 Uhde F Fauser 側の人々に對し「日本にも

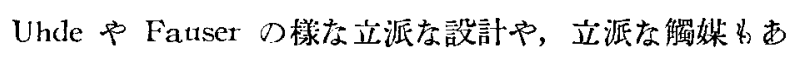
る，之が工業化は碓信を侍つて居る」といふ樣な事を牛

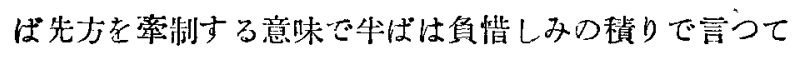
居たが，當時 Uhde 式や Fauser 式の工場を視察した 結果は工業試驗所の設計を工業化するに關する余の確信 を强化せしさるのみであつね。然し余としては沃して日 本式を其疆化すへしとは昭和の人々に勸告した事は一度 もなかつた。然し巴をな事情で故鈴木形長，森專務，高 橋常務等の意向が工菜試驗所式を具體化する方面隹み 一力小寺所長の意志它之と合致するに至り昭和 4 年 4 月 頃昭和肥料硫安計畫の方向が明かに決定するに至つた。 斯くして同年 9 月には余及び余々最初から合成試驗に從 事した中村健次郎上Eの人は昭和肥料に入社し銃意其の

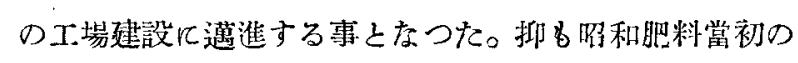
計畫としては年產硫安 5 萬砸位のものでんに對し我々は 日產つムモニア20 画の合成系を一單位として設計を進

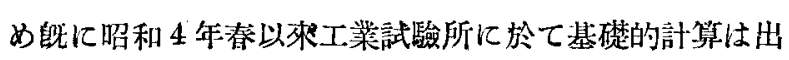
來て居た，然るに其つ後計畫は次第に大きくなり年 8 萬 酣上なり，更に豐水時 8 万月 10 萬䣩となり之が現在の 川衡工場つ硫安計畫の賽際となつた。然し之は豐水時の みならず一年を通して實施する事となり一年約 15 萬䣩 の硫安計畫を鿓施する事よなり，此の量は唯今寞現され て居る凹でする。又工場敷地に就ても色々候補地が擧げ られたが結局神奈川夥川崎市呞田に地所約 53.000 坪を 睡入し此所に建設する牙となつた。昭和肥料川崎工場の 計畫が士業試驗所式で盘施せらるい事の一度世に發表さ れるや，識者上稱する側からも相當存杞真を以て見られ
たっ特に後段述ぶるが如く之に使用する機械裝置を主と

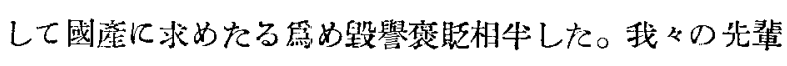
にして外國の方法を移植した人ぬ其の白ら䈏めたであ らら所の經驗からして相當の侮言を放つた。川崎工場の 機峨は迴らない上言ふ人もあつた。川㥓でアムモニアの 埧がしたら首をやると極言する人も西つた。某日刊新聞 にb其の記者が第六感で書いたですら 5 所の隨分中賃的

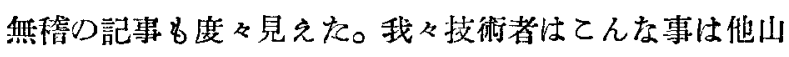
の石として哭つて聞いて濟まされるが，會堷つ金融に當 る人くは相當困つた事であららと思はれる。今日宇部窒 素, 矢作工業及滿洲化學工業等硫安製造の新計畫續出の 折唡，誰か之等に對し我及が蒙つた樣な惡宣傳する者が あららか。外國の方法を其の睢移植するの安心もあら5 が，之れ全く我々が獨自の設計で此つ事業を行ひ硫安工 業は彼等が考へて居学程困難でないといふ事が分つて來 たからではあるまいか。それからてんな話必ある。昭和

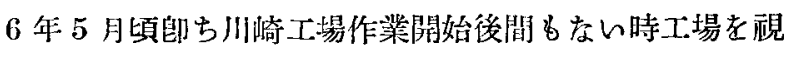
察に桃た某肥料新聞記者が，石灰窎素變成作莱をして居 ないのに硫安が出來てるのを見て、「てんな䈍はない，之 は少し變だぞ，何か誤魔化しがあるんぢやないか」と真

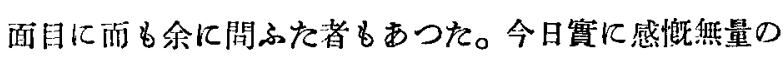
ものがある。

川㥓工場の建設工事閏始は昭利 5 年 9 月中勾であつ

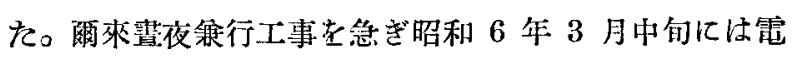
解工場の試運轉が兒事に成功し豫想以上の好成績を故 ね。同月下旬合成一系統の完成と共に其の試運轉に取り か」り前社長鈴木三郎氏の亡くなられた 3 月 29 日頃忙 濑く硫安工場に少し硫安の結晶が出來た頃であつた。我 くはすべて工場に籠城し4月からは僅少の製品を市場に 出すに至つた。工事開始後製品出來まで7ケ月，恐らく 合成硫安工場のレコードを破つたものと思ふっ我々の努

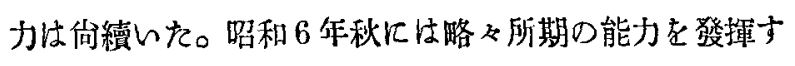
るに至つたのでする。川㥓工場がレコードを破つたのは 浢山ある。先づ外國人心世話にならない我火日本人の力 法でやつた事第一である。工場竣工の速かなる事第二で ある。餘剩電力を沙化する目的で出來た事第三である。 
變 電 亚 變 流設 借 電 線 接 續 圖

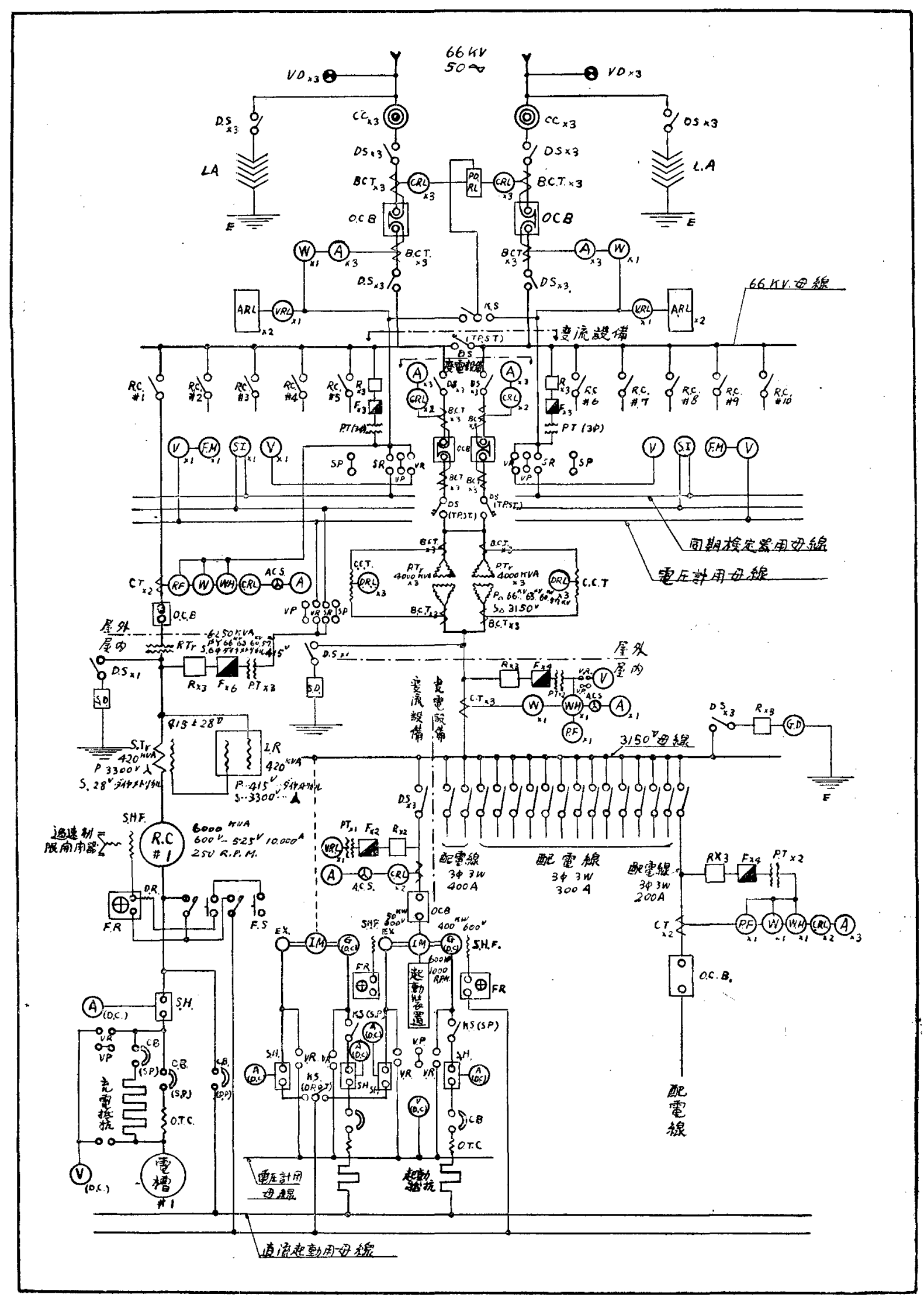


從つて此の結果京

\begin{tabular}{|c|c|c|}
\hline 記 號 & 稱 & \\
\hline A & 流 & 且つ大都术近く \\
\hline A. C. S & 電流計 切替器 & \\
\hline A. R. L & 補 助 繼 電 器 & 場戶 \\
\hline B. C. T & 套管型變流 器 & る事第四である \\
\hline C. $\mathrm{B}$ & 氣 中 進 斷 器 & \\
\hline C. $\mathrm{C}$ & 塞 流 線 輸 & A \\
\hline C. $\mathrm{C} T$ & 補 償 變 流 器 & ぞ全部國产品で而 \\
\hline C. $\mathrm{T}$ & 流 & 䑽捗 \\
\hline O. T. C & 迭電流引外楾輪 & 政通久 \\
\hline C. R. I & 過電流繼電 器 & 最初の經驗で \\
\hline D. & 放 電 抵 抗 器 & \\
\hline D. $\mathrm{R} \mathrm{I}$ & 差 働 繼，電 器 & \\
\hline D. $\mathrm{S}$ & 區 分 開 閉 器 & た事第五である。 \\
\hline $\mathrm{E}$ & 接 & 上, 他雬々 \\
\hline $\mathbf{E}$ & 盛 & 50他楮 \\
\hline$F$ & 聺 & 以下此の川崎工 \\
\hline $\mathbf{M}$ & 波 數 計 & で使用する機䂝 \\
\hline $\mathrm{F}$. & 界 磁 抵 抗 器 & \\
\hline F. S & 界 磁 開閒 器 & に就て大體を \\
\hline $\mathrm{G}$ & 電 & 废的。 \\
\hline
\end{tabular}

\section{3. 川崎工場} 使用機祉

に就て

此のエ場に投下 せられたるE資の 中土地，建物其の 他土术工事考除を 機械類の購入丈け 几約 $10,000,000$ 圆 を要して居る。此 の中外或製の機棫 はドイツ Linde 會 社製の穿溸製造裝 置(此り中空载堅 縮機を除く）及び Iurgi 會䰚製 0 電 氣牧䵇裝置が主な るもので其の他は 小なる計器類のみ で之等は合して約
500,000 圆程度に過ぎない。即ち $95 \%$ は國產の機栈で ある。而して其の間接の影響として本邦化學㝎業機械製 作化對し相當なる經驗と進步とを與へた事を自負する者 である。尤り我々は最初より國喥第一で進んだわけでは ない。我ょの渡歐中は勿論，其れ以前上り此の使用機械 に就ては相當硏究して居たので慢然國座振興の美名に囚 はれたのではない。唯然し我をは㴶歐中各硫安工場の建 設凟金老調查し，之に比較して本邦に於ける此り種工場 の建設費の大なるに一警すると共に，將來世界硫安界に 於て伤遂するに忙可及的建設費の低下を圖る事の絶對的 必要なるを痛感して居沉結果主として國座品採用といふ 結果になつた。本邦製品が安からら惡かららといふなら ば今叉何をか言はんやである。川㥓工場り作業つ概略は

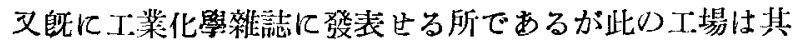
の西方約 $1 \mathrm{~km}$ にある東電鶴兒第一發電所構队にて受電 し甲信及び田代兩系統の電力約 $80,000 \mathrm{~kW}$ 孝受け入れ る，之を 3 相 50 サイタル 66,000 V 2 回線で工場內に 送り込む。

此の工場冈電氣の配線系統は圖に示せる所であるが惯 几工場にて消費する大摬の電力は其の約 $85 \%$ 在水の電 解即ち水素の製造用に偝するのである。アムモニア合成 工業は技街的に考へると合成操作が最も困難なるものた 工場內の心臟であるが，經濟的硫安の製造費から見れば 水菜㹈造が生命である。安くて純粹なる水素こそ合成硫 安工粪つ基礎である。此意味に於て電解装置は極めて大 事なもので之に就ては我をは豫て充分調查して居た。 Knowles, Fauser, Pechkranz, Holnboe, Bamag, Siemens-Schuckert, Electrolab 等の式に就て其の能率,

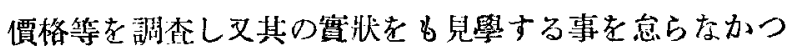
た。同時に又我みは工埄試驗斦にて經驗せる處と外國の 電解槽より得たる暗示等を基礎に一の設計を造り上げ日 立製作所に其の實物試驗を依賴したのは昭和 4 年春の頃 であつた。同製作所にては我々の要求に基いて 10,000 $\operatorname{amp}$ ○直流發電機を作り, 惯物大の賽驗を繰り返され た。此の間スキスの Pechkranz 氏が其の裝置䝴达に來 朝せる際之と色风論議し又数へらるい事もあつた。目 
製作所に於ける電解慒試驗は其の後屢々改良を施され昭 和 4 年末には先進電解慒に少らさる能率のものを造り得 る確信が出來たのである。而して其價格の相談も䌊つて 此電解槽に電流を供給する $6,000 \mathrm{~kW}$ D伵轉變流機 9 臺 (後 1 喜を增加して 10 薹となる)上共に注文する事に決 定したのは實に昭和 4 年大晦日こ西つた。此の日は何處 の會社も役所も休日であつたが我ぬも又日立のうタも隨 分勉强したものだ。爾来日立製作所では一殿㥀重に實驗 老繰り返し昭和 5 年夏の頃上り期の製作に者手し同年末 より工場內に持迟まれて据付に着手し，昭和 6 年 3 月中 旬には一組の試運轉を終へて直ちにつムもニア合成月に 供せられたのである。此の電解槽に就ては燃料協會誌 118 號(昭 7)に概略を發表した。一時相賞に杞虞された 此の電解槽も作業開始以來䄪 2 年大なる事故なく變流機 と組合はされて現在每:日 $288,000 \mathrm{~m}^{3}$ 以上の水素を發生 して居る。電解水素を原料として合成アムモニアを作る エ場としては川崎工場は世界第三位を占むる。此の大な る電解設備は斯る事情と斯る成樍とで使用せられて居る のである。

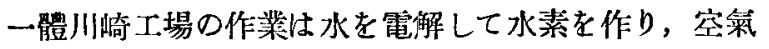
を分溜して空素を作り，此の兩ガスを混合盟縮したる上 䒈媒の作用にてアムモニアを合成するのである。而して 一方硫化鑛石を焙燒して得たる亞硫酸ガスより硫酸を製 造し，硫酸とアムモニアを中和せしめて硫安さするに過

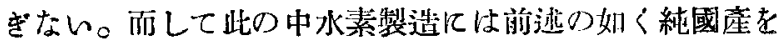

探用する事が出來たが窒素製造には不幸にして之が出來 ない。勿論空素機を國産に俟つ餘裕もなかつたが，又㵋 格の點よりしても大して問題にする程重要とは思はれな レ。Linde, Claude, Messer 等比較研究の上種々の理由 で Linde 式而も空氣壓縮機を除いて之をトイツより資 つたのである。次にアムモニフ合成系に使用する尉縮機 及高筀ガ ス循環機は最初計畫の小さかつた時各 3 荎を石 川舅造船所に墢註した。同所は $1,250 \mathrm{HP} 300 \mathrm{~atm}$ とい ふ大をな且高壓のガス壓縮機の經驗がなかつたが Sulzer 會社より其の圖面を利用して酰縮機つ䌘造家として斯界 に溗り出す契機を作つたのである。而して其の後篔設註

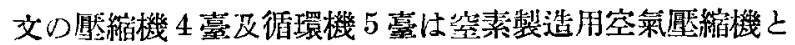
共に神戶製鋼所几註文されたのである。又合成塔其の他

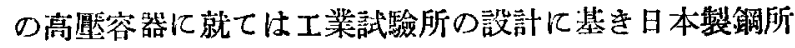
が之を製作する事となり，其の他硫酸製造設備及で硫安 製造設供等すへて國產にて迅速に，低廉に而も便利に完 成されたのである。世界屈指の電雨化學工場は斯くして 全く純日本式に出來上つを事は本邦に於ける斯業の一大

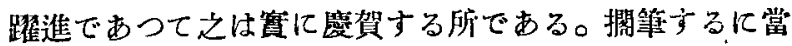
り余は一介の挍術者として當初より余を指導せる小寺所 長北脇部長其の他東京工業試驗所各位及び大英斷以て純

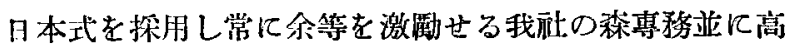
橋常務其の他幹部諸氏，更に川崎工場に於ける設備の艺 成に協力せる各製浩家諸氏の努力に對し滿腔の謝意を表 ナる。

(昭和 8 年 6 月 12 日受理) 